Review

\title{
Tamil traditional medicinal system - siddha: an indigenous health practice in the international perspectives
}

Kaliyaperumal Karunamoorthi ${ }^{1,2^{*}}$, Kaliyaperumal Jegajeevanram ${ }^{3}$, Jerome Xavier ${ }^{4}$, Jayaraman Vijayalakshmi ${ }^{3}$, Luke Melita $^{5}$

${ }^{1}$ Unit of Medical Entomology \& Vector Control, Department of Environmental Health Sciences, College of Public Health and Medical Sciences, Jimma University, Jimma, Ethiopia; ${ }^{2}$ Research and Development Centre, Bharathiar University, Coimbatore, Tamil Nadu, India; ${ }^{3}$ Annai Jagatha Hospital, Karuveppilankurichi - 606 110, Cuddalore District, Tamil Nadu, India; ${ }^{4}$ Government Siddha Medical College, Palayamkottai, Tamil Nadu, India; ${ }^{5}$ Department of Computer Science, Jimma Institute of Technology, Jimma University, Jimma, Ethiopia

\begin{abstract}
Traditional Medicinal System (TMS) is one of the centuries-old practices and long-serving companions to the human kind to fight against disease and to lead a healthy life. Every indigenous people have been using their unique approaches of TMS practice where among, the Chinese, Indian and African TMSs are world-wide renowned. India has a unique Indian System of Medicines (ISM) consisting of Ayurveda, Siddha, Unani, Naturopathy and Homoeopathy. Siddhars are the saints as well as the eminent scholars, who have attained Ashta-mahasiddhi [Tamil: (Ashta-Eight; Mahasiddhi-Power)] or enlightment. They have postulated, practiced, immensely contributed and have established the concept of the Tamil medicinal system called Siddha System of Medicine (SSM). From ancient time, SSM has flourished and has been widely practiced in the southern part of India particularly in Tamil Nadu. The induction of the modern medicinal system has immensely influenced the existence of SSM and has made the SSM principles and practices undervalued/extinct. However, at present, still a considerable group of people are using the SSM as a basic health-care modality. In this context, the present scrutiny deals with the TMS history, its significance with a special reference to SSM history, Siddhars, the basic concept of SSM, its diagnostic procedures, materia medica and treatment. Conclusively, Siddha is one of the most ancient indigenous health practices despite its several thorny challenges and issues, which needs to be flagged effectively and to be preserved and revitalized in the international arena in the near future.
\end{abstract}

Keywords traditional medicinal system, siddha system of medicine, tamilnadu, tamil, siddhar, India

\section{INTRODUCTION}

Application of Indigenous medicine includes a wide range of activities, from physical cures using herbal medicines and other remedies, to the promotion of psychological and spiritual well-being for counseling through the accumulated wisdom of elders. The preparation and dispensing of herbal medicines is one of the most common forms of Indigenous medicine practiced in different parts of the world (Rajagopalan, 1991).

Attention across the world has focused towards alternative systems of medicine (ASM) in the recent past as no medical system is complete for all the ailments encountered. Most of the therapeutic approaches aim at symptomatic relief rather than providing the unambiguous cure to the sickness. Hence, there is a growing interest in traditional systems of medicine that caters to the healthcare needs for a wider population across the globe, especially in the developing countries. Also, the World Health Organization (WHO) recommends the practice of the traditional system of medicine as it is affordable, safe and culturally acceptable (Zhang, 1998).

*Correspondence: Kaliyaperumal Karunamoorthi

E-mail: k_karunamoorthi@yahoo.com

Received February 8, 2012; Accepted May 24, 2012; Published May

31,2012

doi: http://dx.doi.org/10.5667/tang.2012.0006

(C)2012 by Association of Humanitas Medicine

TANG / www.e-tang.org
Traditional system of medicine (TSM)

Traditional system of medicine is often termed "complementary", "alternative" or "non-conventional" medicine (WHO, 2002). "Traditional medicine" is a comprehensive term used to refer both to the traditional medicine (TM) systems such as traditional Chinese medicine, Indian ayurveda and Arabic unani medicine, and to various forms of indigenous medicine.

Practices of traditional medicine vary greatly from country to country, and from region to region, as they are influenced by factors like culture, history, personal attitudes and philosophy. In many cases, their theories and applications are quite different from those of conventional medicine. Long historical use of many practices of traditional medicine, including experience passed on from generation to generation, has demonstrated the safety and efficacy of traditional medicine (WHO, 2000).

\section{History of traditional medicine}

Plants have formed the basis of sophisticated TM practices that have been used for thousands of years by people in China, India, and rest of the other countries (Sneader, 2005). Over centuries, cultures around the world have learned how to use plants to fight against illness and maintain good health. These readily available and culturally acceptable important traditional medicines form the basis of an accessible and affordable health-care regime and are an important source of livelihood 
for indigenous and rural populations (Roberson, 2008).

The use of plants as medicine goes back to the period of early man. Fossil records date human use of plants as medicines at least to the middle Paleolithic age. Evidences of this early association have been found in the grave of a Neanderthal man buried 60,000 years ago. The earliest known medical document is a 4000 -year-old Sumerian clay tablet that recorded plant remedies for various illnesses. By the time of the ancient Egyptian civilization, a great wealth of information already existed on medicinal plants. This information, along with the hundreds of other remedies, has been preserved in the Ebers papyrus for about 3500 years ago (Solecki, 1975; Kong et al., 2003). Some of the earliest records of the usage of plants as drugs are found in the Artharvaveda, which is the basis for Ayurvedic medicine in India [dating back to 2000 Before the Christian Era (BCE)], the clay tablets in Mesopotamia (1700 BCE), and the Eber Papyrus in Egypt (1550 BCE) (Sneader, 2005).

\section{Significance of traditional medicine}

Over one-third of the population in developing countries lack access to essential medicines (WHO, 2003). Furthermore, TM is also highly popular in many developing countries because it is firmly embedded within wider belief systems (WHO, 2002). TM is widely used and of rapidly growing health system and economic importance. In Africa up to $80 \%$ of the population uses TM to help meet their health care needs. In Asia and Latin America, populations continue to use $\mathrm{TM}$ as a result of historical circumstances and cultural beliefs (WHO, 2002).

\section{Traditional medicine: a boon for the rural poor}

In developing countries, broad use of TM is often attributable to its accessibility and affordability. In Uganda, for instance, the ratio of TM practitioners to population is between 1:200 and 1:400. This contrasts starkly with the availability of allopathic practitioners, for which the ratio is typically $1: 20,000$ or less. Moreover, distribution of such personnel may be uneven, with most being found in cities or other urban areas, and therefore difficult for rural populations to access (WHO, 2002).

WHO encourages, recommends and promotes traditional/herbal remedies in national health care programmes because these drugs are easily available at low cost, safe and people have faith in them. The WHO assembly in a number of resolutions has emphasized the need to ensure quality control of medicinal plant products by using modern techniques and applying suitable standards (Chaudhury, 1999; Raina, 2003).

\section{Global renaissance of traditional medicine}

In many developed countries popular use of complementary and alternative medicine (CAM) is fuelled by a concern about the adverse effects of chemical drugs, questioning of the approaches and assumptions of allopathic medicine, and greater public access to health information (WHO, 2002). In China, TM accounts for around $40 \%$ of all health care delivered. Meanwhile, in many developed countries, CAM is becoming more and more popular. The percentage of the population which has used CAM at least once is $48 \%$ in Australia, $70 \%$ in Canada, $42 \%$ in USA, 38\% in Belgium and $75 \%$ in France (WHO, 2002). In a number of industrialized countries many people regularly use some form of traditional complementary and alternative medicine (TCAM) with Germany (75\%), Canada $(70 \%)$ and England (47\%) being examples (WHO, 2003). In many parts of the world expenditure on TM/CAM is not only significant, but growing rapidly.

\section{Indian system of medicine (ISM): an inevitable practice}

\begin{abstract}
Key Terms
Traditional Medicine: WHO (2002) defines traditional medicine as including diverse health practices, approaches, knowledge and beliefs incorporating plant, animal, and/or mineral based medicines, spiritual therapies, manual techniques and exercises applied singularly or in combination to maintain well-being, as well as to treat, diagnose or prevent illness.

Siddha System of Medicine (SSM): An ancient system of medicine prevalent in Tamil Nadu, South India. The word Siddha comes from the Tamil word for perfection. Those who attained an intellectual level of perfection were called Siddhars. Siddha drugs arrest the degeneration of cells in the body. The Siddha system advocates control of breathing and diet. Meditation and yoga are part of the system.

Tamil: Tamil is a Dravidian language predominantly spoken by the Tamil people of the Indian subcontinent. It is not only an official language of Sri Lanka and Singapore, but also spoken by significant minorities in Malaysia, Mauritius and in the emigrant communities around the world. It is one of the longest surviving classical languages in the world. The variety and quality of classical Tamil literature has led to its being described as "one of the great classical traditions" and richest literatures of the world Tamil inscriptions date back to 500 BC. The oldest literary text in Tamil, Tolkāppiyam, was composed around $200 \mathrm{BC}$. The Tamil alphabet is thought to have evolved from the Brahmi script, though some scholars believe that its origins go back to the Indus script (Wikipedia, 2012).
\end{abstract}

The system of medicines which are considered to be Indian in origin or the systems of medicine, which have come to India from outside and got assimilated into the Indian culture are known as Indian systems of medicine (ISM) (Prasad, 2002). The history of medical botany dates back to the origin of civilization. In India, it can be traced back to the 'Vedic' period $(5000$ - 1500 bc $)$. The 'Atharveda' contains detailed information on approximately 2000 medicinal plants and their uses. After the 'Vedic era', the works of 'Charak' and 'Susruta' namely 'CharakSamhita' and 'SusrutaSamhita' deal with 700 drugs of daily and specific uses (Mukherjee et al., 2006). The Indian Materia Medica (IMM) includes about 2000 drugs of natural origin, almost all of which are derived from different traditional systems and folklore practices (Narayana et al., 1998).

India has a population with a high degree of medical pluralism. Medicine in contemporary India is a fascinating blend of traditional system with conventional system and is deeply embedded in nationalist sentiment (Khan, 2006). These medicines are not only adopted by the people of low socio-economic classes but also by higher educated and government employees (Krishnan et al., 2009).The traditionally trained healers are playing a crucial role in the basic health care of rural villagers in many parts of India (Rao et al., 2011).

\section{India: a cradle of traditional medicine}

India has the unique distinction of having six recognized systems of medicine in this category. They are Ayurveda, Siddha, Unani, Yoga, Naturopathy and Homoeopathy. Though Homoeopathy came to India in the $18^{\text {th }}$ Century, it is completely assimilated in to the Indian culture and got enriched like any other traditional system; hence it is considered as a part of ISM (Prasad, 2002). However, three traditional medicinal systems predominate in modern India; Ayurveda, Siddha, and Unani. Ayurveda is found mostly in northern India and in Kerala in the south. Siddha medicine has been in practice in Tamilnadu (Fig. 1) and parts of Kerala. Unani, which derives from Arabic medicine, is found throughout India, mainly in the urban areas (Zysk, 2008). The present review focuses on the Siddha System of Medicine (SSM) (Tamil: Siddha Vaithiyam) and its history, basic principles, diagnostic procedures, Siddha materia medica and, the treatment and 


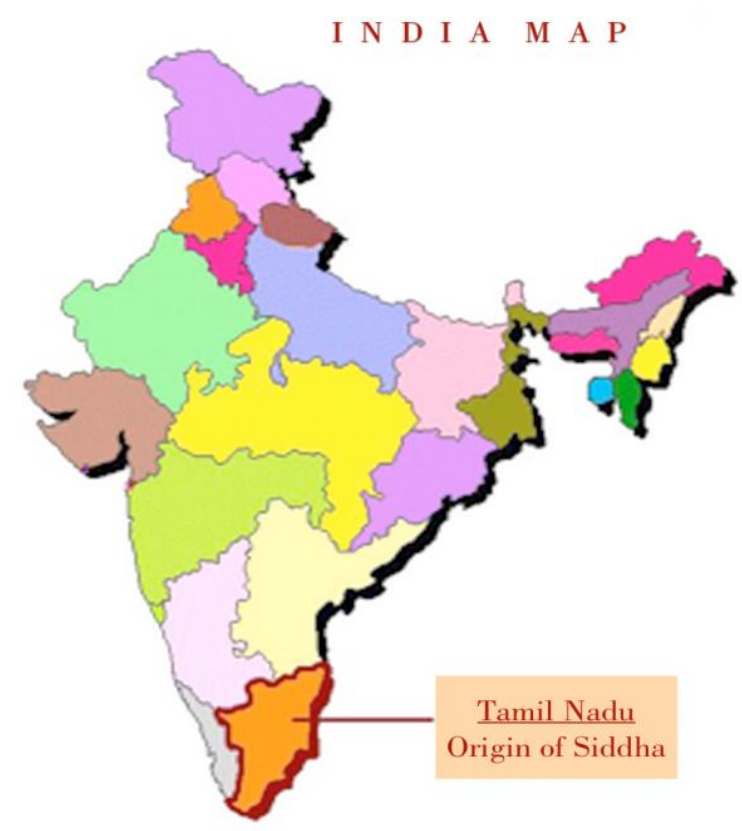

Fig. 1. Location of Tamilnadu in India.

practice in south India. It also describes about the existing major challenges and the opportunities to improve this ancient indigenous Tamil traditional health system in the global perspective in the near future.

\section{Tamil traditional medicinal system: siddha factual history} of siddha system of medicine (SSM)

The SSM is the oldest traditional treatment system generated from Dravidian culture and it is flourished in the period of Indus valley civilization (Mukherjee and Wahile, 2006). Perhaps, it is the foremost of all other medical systems in the world. Its origin dates back to BC 10,000 to $\mathrm{BC} 4,000$ (Sambasivapillai, 1931; Pillai, 1979) and it is the most ancient indigenous system of medicines of Indian origin practiced exclusively in Tamil nadu and in some parts of the neighboring states. The first Tamil siddha text is the Thirumandhiram written by Thirumoolar dating probably to around $6^{\text {th }}$ or $7^{\text {th }}$ century Christian Era or Current Era (C.E) (Zysk, 2008).

The excavatory findings in Harappa and Mohenjo-Daro also reveal the existence of a civilization and medical system and it is consisted of some siddha medicines and idols of Lord Natarajan that was worshipped as per Saiva-Siddhantam which is a part of this ancient civilization. Also, some vessels that were found from these places are said to be the ancient apparatus used to prepare siddha drugs. Hence, the siddha system or "Siddham" is the way of life which is the most ancient of all medical systems (Anonymous, 2011a). Hence, it can be considered that the SSM is the most primordial one. It was only between $1200 \mathrm{BC}$ and $700 \mathrm{BC}$ that the four vedas were composed after the invasion of Aryans (Anonymous, 2011). Siddha medicine has a background of mythology and genealogy too (CCRAS, 2008).

\section{Siddha mythology}

Lord Siva is considered as the first Siddhar. He taught Siddha to his consort Parvathi and in turn she handed it down to Nandhi who has taught the Siddhars. Nandhi taught the Sage Agasthiyar and Agasthiyar to Pulathiyar, Bogar, Theraiyar and others of Pothigai Hills. At Siva temples in various parts of Tamil nadu, the lord is named as Vaideeswaran and Marundeeswaran. The different cultural traditions in the world had affected their medical systems to cater to the needs of their societies suitably like Greek, Chinese, Arabic and Indian. In India, we had two distinct cultures one is vedic and the other one is tantric (CCRAS, 2008).

The sages of south India, who practiced tantrism contributed and established a medical system to serve the humanity in general and their own society in particular. Those sages were called as siddhars and the medical system used by them is called as SSM. Though the creation of this system is ascribed to lord Siva, the creator of the universe, the sage Agasthiyar is considered as a father figure of siddha medical system. He is also considered to be the father figure of the Tamil language and culture (CCRAS, 2008). SSM has been closely identified with Tamil civilization too (Narayanaswamy, 1975).

\section{Tamil: a classical language}

The Tamil nadu which existed several millions of years ago was a vast continent called Lemuria or Kumarikandam. The history reveals that this vast land was eroded and submerged into the sea 15,000 years ago. As a result Tamil nadu which exists today is only a part of that huge continent. According to the books like "History of Creation" and "Pre Degree of Man" written by Hackal, the submerged Tamil land was the first place occupied by mankind who were well civilized (Fig. 1). Tamil nadu is considered as the home of siddhars from where this premordial civilization and medical system evolved. This system was pre-vedic and pre-aryan. It was only between 1200 Before Christ (BC) and 700 BC, when Aryan invaded India and the origination of Sanskrit and other north Indian languages occurred (Anonymous, 2011a).

Tamil is one of the oldest languages in the world, which has got greater antiquity. It was nurtured and developed at different points of time by three Tamil academies (Tamil: Tamil sangam) of which the first Tamil sangam dates back to $3000 \mathrm{BC}$. The oldest Tamil book 'Tholkappiam' is also considered to be written in 3000 BC. The great Tamil scholar K. A. Appadurai states that the culture of the Tamils is the cradle of civilization. The third Tamil academy (Tamil: Kadai sangam) was established in 2000 BC. The books like "Thirukkural" and others are the monumental evidences to evince their antiquity (CCRAS, 2008). SSM is the most ancient of all medical systems and the origination of this civilization dates back to 12,000 years before Christ (Anonymous, 2011a).

\section{Siddhars: great philosophers and physicians}

The major sources of Siddha medicine belong to religious groups called 'Kayasiddhars' and they emphasized on the "Perfection of the body" by means of yoga, alchemy, medicine, and certain types of tantric religious rituals (Zysk, 2008). The philosophy and the medicine are like two sides of the coin. The great philosophers like Aristotle and Galen were the great philosophers and physicians too. The siddhars were also found to be the great philosophers and physicians. It is an indisputable truth that the rich Tamil heritage, the culture and the medical system have got greater antiquity (CCRAS, 2008).

The word "Siddha" denotes "(Tamil: Siddhi)" which means achievement in life arts such as philosophy, yoga, wisdom, alchemy, medicine and above all the art of longevity (Sampath, 1983). Siddhars can also be called as spiritual scientists of Tamil Nadu who explored and explained the reality of nature and its relationship to man by their yogic awareness and experimental findings. They postulated the concept of spiritualism for self-improvement, and the practices initiated by them came to be known as the SSM (Ram et al., 2009). SSM has been in existence and is being practiced for the past 2000 years (Thas, 2008); however the printed Siddha literatures are available from the 18th century onwards and before that they were documented on palm leaves by different authors (Sampath, 


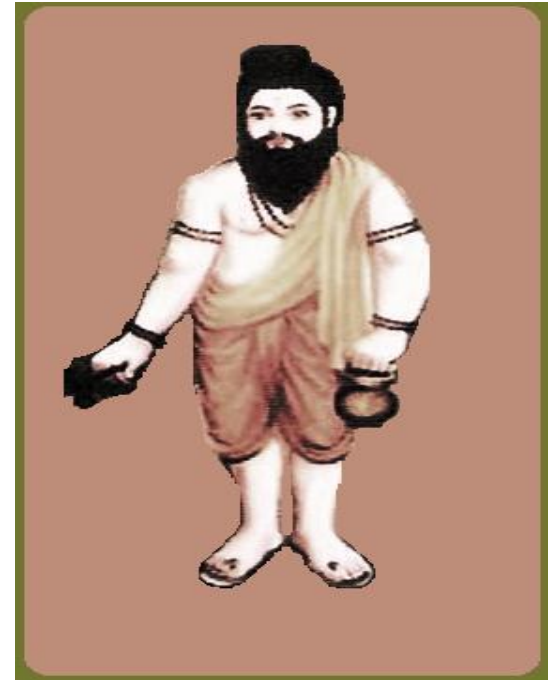

Fig. 2. Agasthiyar.

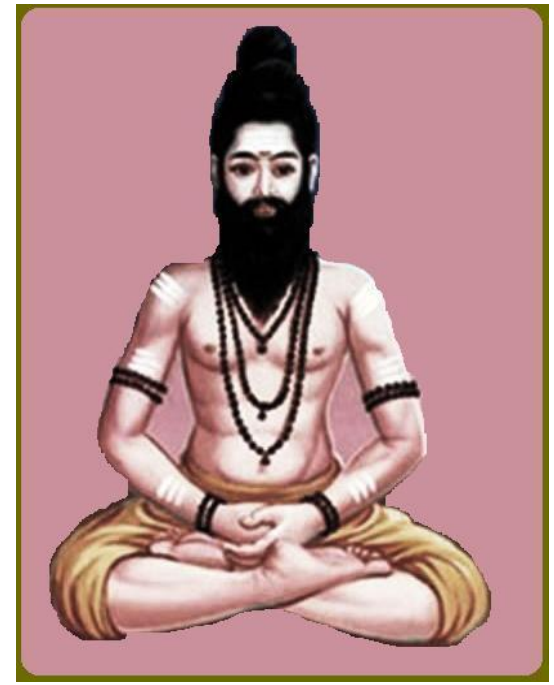

Fig. 3. Thirumoolar.
1983).

Agasthiyar (Fig. 2) has contributed more in the development of SSM and he is considered to be the "Hippocrates of Siddha Medicine", who is one of the greatest philosophers of India (Sampath, 1983). Some of his works are still in standard books of medicine and surgery, which are in the daily use among the siddha medical practitioners. There were 18 important siddhars (Table 1) in the olden days and they developed this system of medicine and hence it is called as SSM (Mukherjee and Wahile, 2006). The dates of these siddhars are uncertain, although Tamil tradition accords remote antiquity to them. However only the later Siddhars like Agastiyar, Thirumoolar (Fig. 3), and Bhogar (Fig. 4) who lived in the fifth and sixth centuries, were able to record it systematically (Subbarayappa, 1997).

The Siddhars wrote their knowledge on palm leaf manuscripts, fragments of which were found in different parts of south India. It is believed that some families may possess some more fragments, but are keeping them solely for their own use. There is a huge collection of siddha manuscripts which are preserved by traditional siddha families (Mukherjee and Wahile, 2006).

\section{Siddha system of medicine: a conquest of death}

Siddhars had a firm faith in the "Deathless" physical body being in tune with the spiritual immortal "Soul" and significantly one of the definitions of siddha medicine is the conquest of death: "that which ensures preventive against mortality". This statement is attributed to Thirumoolar; a revered siddha whose treatise called 'Thirumanthiram' has 3000 stanzas and is regarded as a classic text on the basic philosophy of siddha medicine (Shanmuga Velan, 1963).

\section{Siddha system of medicine basic concepts}

According to SSM, the human body is composed of 96 factors (Tamil: Thathuvas) which include physical, physiological, psychological and intellectual aspects. There are 72,000 blood vessels and 1300 nerves and the total number of diseases is 4,444. Besides these, there are 10 main arteries (Tamil: Naadi),
10 vital pranas (Tamil: Vayu) and 10 natural functions (Tamil: Vegangal). All of these are said to play important roles in the different functions of the body (Walter, 2005). The Siddha practitioner is expected to have knowledge on the four basic concepts (WHO, 2005);

- Alchemy (Tamil: Vaatham)

- Medicine (Tamil: Vaithiyam)

- Yoga (Tamil: Yogam)

- Philosophy (Tamil: Thathuvam)

The use of metals such as gold, silver, iron, lead and mercury, and extracts of corals and pearls, is a special feature of siddha medicine, which claims to detoxify metals to enable them to be used for stubborn diseases.

\section{Basic principles}

According to the siddha concepts matter and energy are the two dominant entities, which have great influence in shaping the nature of the universe. They are called Siva and Sakthi in the siddha system. Matter cannot exist without energy and vice-versa. Thus both are inseparable (Narayanaswamy, 1975). The SSM is a psychosomatic system of medicine that deals with the relationship between the mind and body and aims at maintaining the physical, mental and moral health of an individual.

As per SSM, man is regarded as the microcosm and the universe, macrocosm. The living man is the conglomeration of three humours (Tamil: Three thodam/mukkutram) vaatham, pitham and kabham, seven basic tissues (Tamil: Saptha dathukkal) and five primordial elements viz., (Tamil: Panchabhootham) - earth (Tamil: Mann), water (Tamil: Neer), fire (Tamil: Thee), air (Tamil: Katru) and space (Tamil: Aahayam). A suitable proportion of these five elements, in combination with one another are responsible for the different structures and functions of the body matrix. This is known as the theory of "five-fold combination" (Tamil: Pancheekaranam) (Uthamaroyan, 1983).

Uyir thathukkal (three humours)

Uyir thathukkal literally means 'life force'. In siddha, vaatham,

Table 1. Name of the Siddhars in order of their time period

\begin{tabular}{|c|c|c|c|c|c|}
\hline 1. & Shri Pathanjali & 2. & Shri Agasthiyar & 3. & Shri Kamalamuni \\
\hline 4. & Shri Thirumoolar & 5. & Shri Kuthambai & 6. & Shri Korakkar \\
\hline 7. & Shri Thanvantari & 8. & Shri Sundaranandar & 9. & Shri Konganar \\
\hline 10. & Shri Sattamuni & 11. & Shri Vanmeegar & 12. & Shri Ramadevar \\
\hline 13. & Shri Nandeeswarar & 14. & Shri Edaikkadar & 15. & Shri Machamuni \\
\hline 16. & Shri Karuvoorar & 17. & Shri Bogar & 18. & Shri Pambaati \\
\hline
\end{tabular}

TANG / www.e-tang.org 


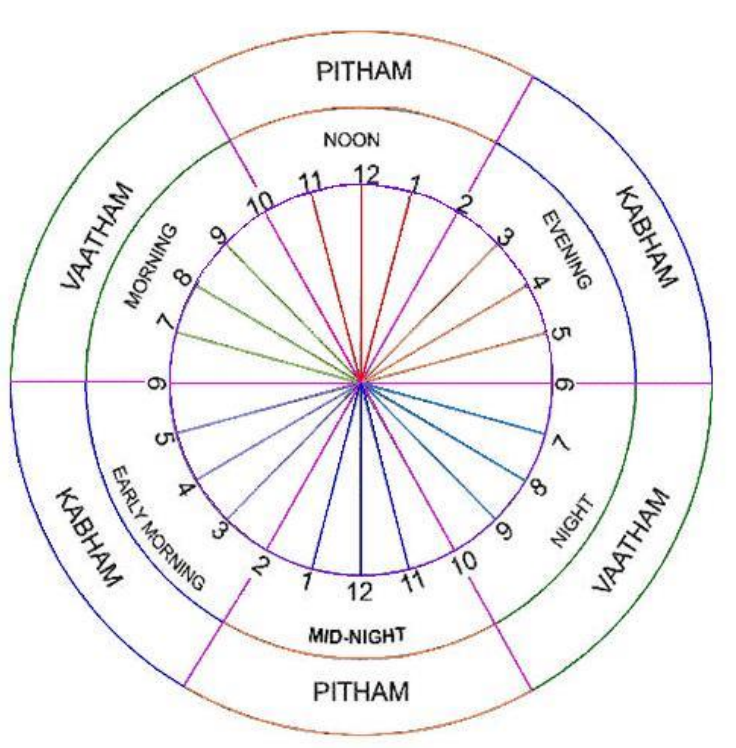

Fig. 5. Six periods (Siru Pozhuthu) in a day.

pitham and kabham which are the three humours, are responsible for the creation, preservation and destruction of the human body and health. When they are in the state of equilibrium (4:2:1-the ratio in which they exist) our body remains in a healthy state while any disturbance in this ratio leads to a diseased state or death (CSIR-AYUSH, 2012);

- Vaatham - Represents the elements 'air' and 'space'. It is responsible for all the movements of the mind and body. Motor and sensory activities are said to be governed by vaatham.

- Pitham - Represents the element-'fire' in our body and is responsible for the preservation of health. It maintains the body heat for normal physiology and dominates the chest and abdominal areas.

- Kabham - Formed by the elements 'earth and water'. It is responsible for strength, joint movements, body built and endurance. It dominates the head and neck regions.

Each day, is divided into six periods of four hours each, which is called the smaller period (Tamil: Siru Pozhuthu) (Fig. 5). Every year, on the other hand, is divided into six seasons of two-month duration each, which is called the longer period (Tamil: Perum Pozhuthu) (Fig. 6). The effects of seasons on the incidence of diseases have been defined and further, seasonal conduct has been advised to prevent these diseases. A single humour (Tamil: Uyir dhathu) dominates over the other two in a particular season and during any specific period of a day, and hence the food habits and other lifestyles must be tuned in accordingly for healthy living (CSIR-AYUSH, 2012).

\section{Seven basic tissue types (Tamil: sapta dathus)}

SSM recognizes seven types of essential tissues in the body which support all other tissues in its life and functions. These tissue types are called the seven dathus, which are the following (CCRAS, 2008);

- Lymph (Tamil: Rasa) - The importance of lymph was recognised by Siddha physicians from very early periods. Lymph is considered to be the carrier of nutrients from the digestive process, and a disorder of the lymph is dealt with in a serious manner.

- Blood (Tamil: Kurudhi) - Blood and human life are inter-woven with one another. The disorders of blood or its reduced ability to function is a prime cause of disease.

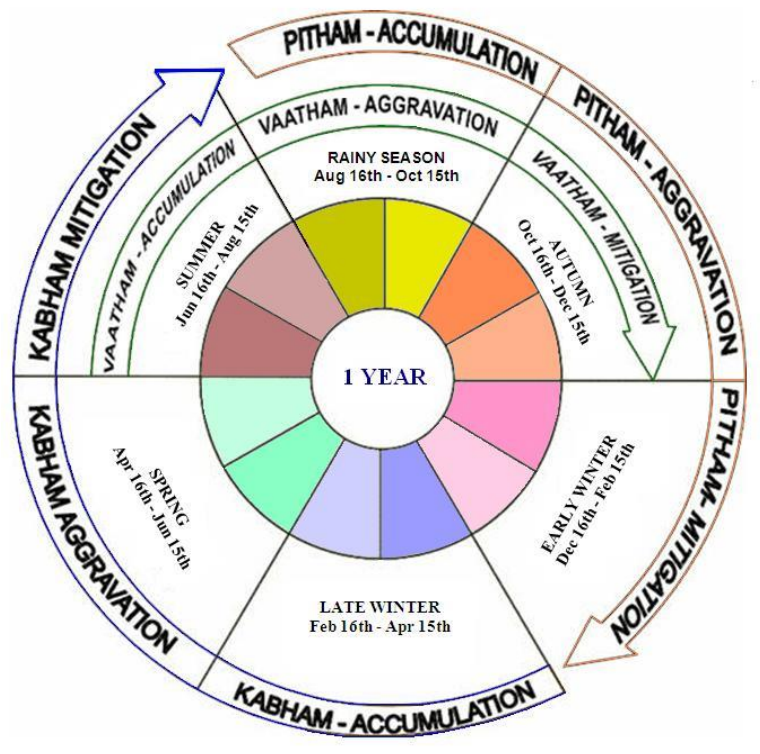

Fig. 6. Six seasons (Perum Pozhuthu) in a year.

- Muscle (Tamil: Thasai) - Muscles are important to give strength to body activities. Loss of muscle strength causes immobility and imbalance in the body. Conversely, an imbalance of Vatta can cause muscle tissue to suffer from immobility imposed on it due to symptoms such as pain.

- Adipose Tissue (Tamil: Kozhuppu) - Fatty tissue plays a very important role in the human body. Fat is part of lipoproteins and many other hormones. It is the other half of proteins in the make-up of the cell membrane, the most intelligent entity in the cell next to DNA.

- Bone (Tamil: Elumbu) - Bone provides the primary physical foundation for a human being. It also acts as a safe area for the marrow tissue and is a depot of calcium, without which muscular activities are impossible.

- Marrow (Tamil: Majjai) - Healthy marrow is important not only to manufacture healthy blood but also for a strong immune system, since bone marrow is the area of blood-cells formation viz., red, white and platelets.

- Semen and Menstrual fluids (Tamil: Sukkilam and Artavam) - These are highly conserved tissues in the body. SSM maintains that the emission of sperm should not happen more than once a day. This gives rest for the testis and adequately conserves valuable resources and emissions. More than once a day can cause many diseases and disorders generally called disorders of "madam". The same is the case of Arthavam or the menstrual fluids. A heavy menstrual flow or passing clots is considered as a sign of imbalance and should be corrected without fail.

\section{Concept of pathogenesis}

It is assumed that when the normal equilibrium of three humors (vatham, pitham and kabham) is disturbed, disease is caused. The factors assumed to affect this equilibrium are environment, climatic conditions, diet, physical activities, and stress. Under normal conditions, the ratios between these three humors are 4:2:1, respectively. According to the SSM, diet and life style play a major role not only in health but also in curing diseases. This concept of the siddha medicine is termed as pathya and apathya, which is essentially a list of do's and don'ts (CSIR-AYUSH, 2012).

Diagnostic methodology 
The siddha diagnostic methodology is based on the clinical examination of the physician and these diagnostic tools not only help for diagnosis but also to learn the prognosis of the restoration of health. Siddha physicians base their diagnosis on three humors (Tamil: Mukkuttram) and eight vital tests (Tamil: Ennvagai Thervu) (Walter, 2005). The identification of causative factors is diagnosed through the examination of the following eight vital tests;

- Pulse reading, (Tamil: Naadi - Vatha, Pitha and Kabha)

- Urine examination, (Tamil: Neer kuri \& Neikuri)

- Examination of faeces, (Tamil: Malam)

- Examination of eyes, (Tamil: Kangal)

- Study of voice, (Tamil: Mozhi - Kural)

- Color of body, (Tamil: Niram)

- Examination of the tongue (Tamil: Naa) and

- Status of the sensation of human body (Tamil: Sparism).

Among these, urine examination (Tamil: Neerkuri) is the major diagnostic method. The color of the urine, smell, density, quantity and froth are noted in almost all systems of diagnosis and Neikkuri is a method, in which the surface tension and the pattern of gingelly oil (Tamil: Nallennai) spreading on the surface of the urine also provide valuable information in diagnosing the diseases (Krishnamurthy and Chandramouli, 1984; Saroja and Veluchamy, 1983). In addition, pulse examination is also the most prominent diagnostic procedure in SSM. In other words, it performs the job of present day inventions like the stethoscope and sphygmomanometers (Wujastyk, 1995). The pulse examination is done for females on the left hand and for males on the right hand (Zysk, 2008).

\section{Siddha materia medica: secrecy}

Siddha is largely therapeutic in nature and comprises of alchemy, philosophy, yoga, mantra and astrology (Pillai, 1979; Hausman, 1996). Since time immemorial, in the siddha system of medicine, the heritage of the family practice of south India, is a special, scientific, significant, most respectable and of high order one. In Tamil literature, the word marunthu (drug) itself means or denotes scented root or leaf. The SSM is mainly concerned with the development of drugs, which have high potencies and long lives for their use in the future. It also aims to activate the generation of cells and to maintain the longevity (Sampath, 1983; Narayanaswamy, 1983; Rao and Veluchamy, 1983; Krishnamurthy and Chandramouli, 1984).

Drugs of SSM are used separately or in combination for maintaining this normal ratio. The combined drugs are classified into two categories: enemy (Tamil: satru) and friend (Tamil: mitru). The modern equivalent terms are compatible (potentiating the action of one drug by another) and incompatible (one drug antagonizes another and reduces the therapeutic action) (Narayanaswamy, 1983).

The materials used by the siddhars as drugs could be classified into herbal (Tamil: Mooligai/Thavaram), inorganic substances (Tamil: Dhathu) and animal products (Tamil: Jeevavaguppu), which are characterized by means of taste (Tamil: Suvai), quality (Tamil: Gunam), potency (Tamil: Veeryam), post-digestive taste (Tamil: Pirivu), and specific action (Tamil: Prabhavam), while Ayurveda recognizes all the drugs only by quality as the main character (Subbarayappa, 1997; Krishnamurthy and Chandramouli, 1984; Zysk ,2008).

\section{Herbal drugs (Tamil: Mooligai/Thavaram):}

In general, among the Indian systems of medicine (ISM), Siddha uses herbs prominently. Great emphasis is given to herbs by our ancient Siddhars. In Bogar Nikandu, about 4,444 diseases are described and various herbs are indicated for these diseases (Somasundaram, 1997). It has been stressed by the siddha sutra as follows; "Verparu thazhaiparu minginikal Mellamella parpachenduram pare"

Accordingly, it has been advised to administer the first pure herbs in the form of liquid, powder, pill or paste. If this does not control the disease then, the physicians will use the mixture of herbs, metals, minerals and animal products in addition to the herbs.

\section{Inorganic substances (Tamil: dhathu)}

The SSM has developed a rich and unique treasure of drug knowledge in which use of metals and minerals is liberally made. The drugs are categorized under the following categories (Ravishankar and Shukla, 2007);

- Uppu (water soluble inorganic substances or drugs that give out vapour when put into fire) There are 25 varieties of water-soluble inorganic components called 'UPPU'. These are different types of alkalies and salts.

- Pashanam (drugs not dissolved in water but emit vapour when burnt). There are 64 verities of mineral drugs that do not dissolve in the water but emit vapours when put in fire. Thirty-two of these are natural products and the remaining are synthetic.

- Uparasam (similar to pashanam but differ in action), there are seven drugs that do not dissolve in the water but emit vapour on heating.

- Loham (not dissolved in water but melt when fired) The system has classified separately, the classes of metals and alloys, which melt when heated and solidify on cooling. These include items like gold, silver, copper, tin, lead and iron. These are incinerated by special processes and used in medicine.

- Rasam (drugs which are soft) There is a group of drugs that exhibit sublimation on heating and includes mercury and its different forms like red sulphide of mercury, chlorides of mercury and red oxide of mercury etc.,

- Ghandhagam (drugs which are insoluble in water, like sulphur). Sulphur, which is insoluble in water, finds a crucial place in siddha material medica along with mercury for use in therapeutics and in the maintenance of health.

\section{Animal products (Tamil: Jeevavaguppu)}

From the animal kingdom thirty-five products have been identified in the siddha materia medica. It is much similar to the preparations of Ayurveda (Ravishankar and Shukla, 2007). Siddha system used animal products such as human and canine skulls in the preparation of special "ash" (Tamil: Chunnam) which is said to be effective against mental disorders (Zysk, 2008).

According to their mode of application the siddha medicine could be categorized into two classes (CSIR-AYUSH, 2012);

- Internal medicines which are classified in to 32 categories based on their forms, methods of preparation, shelf lives, etc are administered through the oral route.

- External medicines include certain forms of drugs and also certain applications like nasal, eye and ear drops and also certain procedures like leech application. It is also classified in to 32 categories.

\section{Kaya Kalpam}

To elevate the soul on its spiritual journey, the Siddhars formulated an applied alchemy, the Kaya Kalpam (Kaya - Body, mind and psyche and Kalpa - Transmutation). According to Siddha Materia Medica, Kayakalpa formulations include Herbs, Minerals and Animal kingdom also. Kayakalpa is a transformative approach to health and consciousness to prevent and to be freed from the chronic diseases. Besides rejuvenating 
the body, it also possesses prophylactics actions (Rajalakshmi et al., 2006).

\section{Principles of treatment}

The SSM is a psychosomatic system, where attention is given to minerals and metals along with the plant constituents (Mukherjee, 2001). The treatment in siddha medicine is aimed at keeping the three humors in equilibrium and in the maintenance of the seven elements. Therefore, proper diet, medicine and a disciplined regimen of life are advised for a healthy living and to restore equilibrium of humors in a diseased condition. According to the SSM, various internal and biological features of your appearance are assigned to the blend of seven elements viz., plasma, blood, muscle, fatty tissue, bone, nerve and semen (Ayu, 2012).

Siddha system follows the ashtanga concept with regards to treatment procedures. However, the main emphasis is on the three branches, namely pediatrics (Tamil: Bala vahatam), toxicology (Tamil: Nanjunool) and ophthalmology (Tamil: Nayana vidhi). The other branches have not been developed to the extent seen in Ayurveda. The surgical procedures, which have been explained in great detail in the ayurvedic classics, do not find mention in the siddha classics. The therapeutics in both the systems can be broadly categorized into samana and sodhana therapies. The latter consists of well-known procedures categorized under panchakarma therapy. This therapy is not that well developed in siddha system, only the vamana therapy has received the attention of the siddha physicians (Narayanaswamy, 1975).

\section{Ethical guidelines for SSM treatment}

Descriptive ethical guidelines are found in the classic siddha literature, "Theriyar Yamaga Venba" by the great Siddhar Theraiyar (Walter et al., 2009);

- The best days in a week to start treatment are Sundays and Mondays while, Wednesday and Saturday are not considered as good days and Friday and Thursday and Tuesdays are considered as better days.

- The best month for treatment April 14 - June 15 (Tamil months: Sithirai and Vaikasi) are considered as the best month for treatment as, the waste toxins of the body tend to get removed automatically during that period. June $16-$ August -15 (Tamil months: Aani and Aadi) are considered to be the period of $2^{\text {nd }}$ preference. The months from August 16 - April 13 (Tamil months: Aavani to Panguni) are of the 3rd quality and unfit for treatment, since the waste toxins remain in the body, and any medicines consumed during that period, does not exhibit full efficacy.

\section{Present status of SSM in treatment}

It is believed that the SSM is capable of treating all types of diseases in particular it is effective in treating chronic cases of liver, anaemia, prostate enlargement, piles and peptic ulcer (Haddad et al., 1998). It is also effective in treating skin diseases (Thas, 2008) and arthritis (Wilson et al., 2007). Recently Siddha has been proved by scientific research and by involving viral load assays and CD4+/CD8+ ratios tests, that it is more potent in the management of HIV/AIDS (Paradela et al., 1996) which reduces its highly debilitating conditions (Deivanayagam et al., 2001). It has also been observed to cure HIV/AIDS positive and sexually transmitted diseases (STD). Other diseases such as cancer (Tamil: Putrunoi) and diabetes (Tamil: Neerazhivu noi) can also be treated with Siddha drugs (Veluchamy and Ravi Shankar, 1986) and this has been demonstrated scientifically too (Bhavapriya et al., 2001; Kar et al., 2003; Ranga et al., 2005; Sowmyalakshmi et al., 2005; Veena et al., 2007).

\section{The current role of WHO on traditional medicine}

WHO's mission in essential drugs and medicines policy is to help save lives and improve health by closing the huge gap between the potential that essential drugs have to offer and the reality that for millions of people - particularly the poor and disadvantaged - medicines are unavailable, unaffordable, unsafe or improperly used. It does this by carrying out a number of core functions: articulating policy and advocacy positions, working in partnership, producing guidelines and practical tools, developing norms and standards, stimulating strategic and operational research, developing human resources and managing information (WHO, 2002).

\section{Thorny issues \& challenges in SSM}

To maximize the potential of TM/CAM as a source of health care, a number of issues must be first tackled. They relate to: policy; safety, efficacy and quality, access; and rational use (WHO, 2002). Despite its existence and continued use over many countries, and its popularity and extensive use during the last decade, traditional medicine has not been officially recognized in most countries. Consequently, education, training and research in this area have not been accorded due attention and support. The quantity and quality as well as the safety and efficacy of data on traditional medicine are far from sufficient to meet the criteria needed to support its use worldwide. One of the reasons for the lack of research data is due to health care policies (WHO, 2000).

SSM literature is entirely in the older script of Tamil mostly on palm leaves. Unfortunately, no systematic attempt has been made, so far, either by Tamil savants or by the siddha medical practitioners, to render critical evaluation of the age old traditional system of medicine. This is due to the enigmatic nature of the texts and secretive attitude of Siddha practitioners (Subbarayappa, 1997).

There had been several traditional medicinal practices in Tamil Nadu from time immemorial (Egnor, 1983). The traditionally trained siddha healers were sometimes misidentified as folk practitioners. These traditionally trained siddha healers are still playing a major role in the health care of villagers in many parts of India (Rao et al., 2011). Owing to the decreased revenue generation and hence the social status of these healers, and the knowledge transmission being more-often oral now-a-days (Pandikumar et al., 2011), their knowledge is comparatively more vulnerable than the documented traditional knowledge (Mutheeswaran et al., 2011).

Numerous plants seem to be used in SSM; but there is no adequate data because of multiple reasons. The top two of them are as follows; 1) it is only in ancestral use and inherited by disciple to disciple and generation to generation and 2) it was documented in scholarly Tamil language with numerous cryptic references which differs from the today's common Tamil language and is difficult to understand even by native Tamil people also (Veluchamy and Thayagarajan, 1983). Moreover, the SSM literature has to be translated into other languages in particular English and therefore a majority of the people other than Tamilians shall be able to understand and practice. This type of effort will popularize this indigenous medicinal practice in the world arena.

There are many studies are reporting that siddha drugs are effective to treat various ailments. Therefore, a critical examination and identification of crude drugs is required in the manufacture of herbal formulation due to the great diversity and variability in their chemical characters. To overcome this problem all the pharmacopoeias have also laid down certain standards (Ekka et al., 2008).

The chemicals from traditionally useful medicinal plants 
could serve as good prototypes for rational drug discovery (Patwardhan and Vaidya, 2010) to yield safe chemical entities than other synthetic chemicals entering first-in-man studies (Patwardhan and Mashelkar, 2009) in a more productive and economic way (Holland, 1994). Thus, the concept of 'reverse pharmacology' seems to be a more attractive option for drug discovery (Mutheeswaran et al., 2011).

- In industrialized nations, herbal medicine is now a multibillion dollar industry, and in developing countries, up to $80 \%$ of people rely on plant-based medicines. The identity, authenticity, and quality of crude plants are often uncertain and difficult to assess (Morris 1998).

- Standardisation is possible for the few herbs for which all active ingredients are known (panel), but is technically difficult and would make drugs unaffordable in developing nations (Morris 1998)

- "One of the main hurdles in the growth of the Indian system of medicine (ISM) sector is the plethora of agencies and laws governing this sector. Each state has its owns et of rules and legislations. Because of this, the movement of plant material from one part of the country to another may take several weeks, and volatile ingredients of the plant may get lost on the way" (Sharma, 2001).

Although, there are wide arrays of treatment modalities in the SSM practiced by a number of physicians, well-organized, preclinical and clinical trial evidences is not adequately available in order to advocate their scientific merits and supremacies over the existing therapies. Hence, scientific validation of the safety and efficacy of the siddha drugs both individually as well as formulations have to be studied in a systematic and organized manner to compete in the international market (Wilson et al., 2007).

Though centuries and several millenniums have passed, SSM is still confined within Tamil nadu, in the hands of small groups of traditional vaidhyars (practitioners). Even the Royal kings had been provided with the kayakarpa treatment. Some traditional practitioners have taught this science to their children which has been confined within their families only. The secrets of preparing medicines, mode of treatment and the precious books as well as the siddha literatures have been kept hidden by them. Even today these missing links or hidden secrets are said to be preserved in such families where this traditional system is practiced. They can't be blamed completely for suppressing these secrets. This is because of their fear of disclosing these secrets that may get misused or to prevent from reaching the wrong persons. Hence this medical system could not flourish. But this science has been converted into a new form in Sanskrit by the Aryans and has been named Ayurveda. With independence, the other medical systems have extended to each nuke and corner of the country (Anonymous, 2011a).

Recently, there has been a resurgence of traditional medical systems the world over, based on the holistic nature of their approaches to healing (WHO, 2002). The efficacy of indigenous systems has been proved in various contexts. Hence, the usage of Siddha that has strong cultural and historical bonds with the people of Tamilnadu has become increasingly relevant. In a heterogeneous public domain, a wide array of factors such as economic status, psychological state, social behavior and occupation are known to influence the practice of the traditional system of medicine (Richard, 1965; Robert et al., 1968; Paul et al., 1987; Dunlop et al., 2000; Sarwade and Ambedkar, 2002). WHO currently encourages, recommends and promotes traditional as well as natural remedies in national healthcare programmes, as they are easily available at low cost, comparatively safe, and are culturally acceptable.

\section{CONCLUDING REMARKS AND FUTURE PERSPECTIVES}

Globally, since time immemorial, each and every society has had its their unique way of indigenous health practice system in order to treat various ailments. The induction of modern health care services has posed immense threat to indigenous health practices due to their potential speedy therapeutic effect. In the past, the traditional medicinal systems are disappearing, displaced, and undervalued by the people. However, TMS have been playing the major role for the rural poor and act as a natural boon in the developing countries. Besides, there is a world-wide resurgence for TM due to its user-friendly nature and the intrinsic side effects of modern medicines. Indeed, India, a homeland of traditional medicine, is known as the ISM, consisting of Ayurveda, Siddha, Unani and Homeopathy.

The Tamil traditional medicinal system, the so called SSM, is an ancient indigenous practice the flourished and practiced for many centuries in Tamil Nadu, India. The basic principle of the SSM is, "food itself is a medicine" which was postulated by the great 18 sages called Siddhars. The Siddha Materia Medica (SMM) was written in the palm by these Siddhars. The million-year old Siddha literature indicates that the SSM can cure many chronic diseases. At the moment there are numerous scientific findings that support the potentiality of the SSM to treat various skin and sexually transmitted diseases, particularly HIV. However, there are many challenges and issues that need to be properly addressed to preserve this age-old indigenous health practice by conducting more research and development on the toxicity and potentiality of SSM preparations.

\section{ACKNOWLEDGEMENT}

We are greatly indebted to Mrs. Melita Prakash for her sincere assistance in editing the document. My last but not the least heartfelt thanks go to my colleagues of our Department of Environmental Health Science, College Public Health and Medicine, Jimma University, Jimma, Ethiopia, for their kind support and cooperation.

\section{CONFLICT OF INTEREST}

The authors do not have any conflict of interest in the present study.

\section{REFERENCES}

Anonymous, 2011. Fundamentals of Siddha medicine. Available at: http://siddham.in/category/fundementals-ofsiddha-medicine (accessed on $19^{\text {th }}$ January 2012).

Anonymous, 2011a. Available at: http://siddham.in/why-issiddha-system-not-recognised-by-the-world-like-other-medical -systems. (accessed on $19^{\text {th }}$ January 2012).

Ayu. Siddha Medicine. Available at: http://ayuworld.org/ complimentary_medicine/siddha_medicine.htm. (accessed on $22^{\text {th }}$ January 2012).

Bhavapriya V, Kalpana S, Govindasamy S, Apparanantham T. 
Biochemical studies on hypoglycemic effect of Aavirai kudineer: a herbal formulation in alloxan diabetic rats. Indian $\mathbf{J}$ Exp Biol. 2001;39:925-928.

Bodeker G, Burford G, Grundy C, Ong CK, Shein K. WHO Global Atlas of Traditional, Complementary and Alternative Medicine. (World Health Organization: WHO Kobe Centre), 2005.

CCRAS 2008. Central Council for Research in Ayurvedic Sciences. Siddha. Available at: http://www.ccras.nic.in/Siddha/ 20081011_OriginOfSiddha.htm (accessed on $19^{\text {th }}$ January 2012).

Chaudhury RR. Herbal medicine for human health. World Health Organization Geneva. (New Delhi, India: CBS publishers and distributors LTD), 1999.

CSIR- AYUSH. 2012. Siddha-Basic Concepts and Principles. Available at: http://www.tkdl.res.in/tkdl/langdefault/Siddha /Sid_Siddha_Concepts.asp?GL=Eng (accessed on $28^{\text {th }}$ January 2012).

Deivanayagam CN, Krishnarajasekhar OR, Ravichandran N. Evaluation of Siddha Medicare in HIV disease. J Assoc Physicians India. 2001;49:390-391.

Dunlop S, Coyte PC, Mclssaac W. Socio-economic status and the utilization of physicians' services: results from the Canadian National Population Health Survey. Soc Sci Med. 2000;5:123-133.

Egnor MJ. Death and nurturance in Indian systems of healing. Soc Scie Med. 1983;17:935-945.

Ekka NR, Namdeo KP, Samal PK. Standardization Strategies for Herbal Drugs-An Overview. Res J Pharm Tech. 2008;1: 310-312.

Haddad S, Fournier P, Potvin L. Measuring lay people's perceptions of the quality of primary health care services in developing countries. Int J Qual Health Care. 1998;10:93-104.

Hausman GJ. Siddhars, Alchemy and the Abyss of Tradition: 'Traditional' Tamil Medical Knowledge in 'Modern' Practice. (Michigan, U.S.A: University of Michigan), 1996.

Holland BK. Prospecting drugs in ancient texts. Nature. 1994;369:702.

Kar A, Choudhary BK, Bandyopadhyay NG. Comparative evaluation of hypoglycaemic activity of some Indian medicinal plants in alloxan diabetic rats. J Ethnopharmacol. 2003;84:105-108.

Khan S. Systems of medicine and nationalist discourse in India. Soc Sci Med. 2006;62:2786, 2797.

Kong JM, Goh NK, Chia LS, ChiaTF. Recent advances in traditional plant drugs and orchids. Acta Pharmacol Sin. 2003;24:7-21

Krishnamoorthy KH, Chandramouli G. Siddha system of medicine: a historical appraisal. Indian $\mathrm{J}$ History Sci. 1984;19:43-53.
Krishnan A, Bagyalakshmi P, Ramya S, Jayakumarraraj R. Current trends in usage of traditional system of medicine in Tamil Nadu, India - from the perspective of occupation. Ethnobot Leaflets. 2009;13:147-151.

Morris K. Tackling thorny issues of herbal medicines worldwide. Lancet. 1998;351:1190.

Mukherjee PK, Wahile A. Integrated approaches towards drug development from Ayurveda and other Indian system of medicines. J Ethnopharmacol. 2006;103:25-35.

Mukherjee PK. Evaluation of Indian traditional medicine. Drug Informat J. 2001;35:631-640.

Mutheeswaran S, Pandikumar P, Chellappandian M, Ignacimuthu S. Documentation and quantitative analysis of the local knowledge on medicinal plants among traditional Siddha healers in Virudhunagar district of Tamil Nadu, India. J Ethnopharmacol. 2011;137:523-533.

Narayana DBA, Katayar CK, Brindavanam NB. Original system: search, research or re-search. IDMA Bulletin. 1998;29:413-416.

Narayanaswamy V. Ayurveda and Siddha system of medicineA comparative study. Subramanian S.V. and Madhaven V.R., (Eds), Heritage of Tamil Siddha medicine. (Madras, India: International Institute of Tamil Studies), pp. 568-576, 1983.

Narayanaswamy V. In: Introduction to the Siddha System of Medicine. (Madras, India: Research Institute of Siddha Medicine), 1975.

Pandikumar P, Chellappandian M, Mutheeswaran S, Ignacimuthu S. Consensus of local knowledge on medicinal plants among traditional healers in Mayiladumparai block of Theni District, Tamil Nadu, India. J Ethnopharmacol. 2011;134:851-864.

Paradela A, Rivas C, Fernandez- Guerrero M, Roman A. Histopathology of bone marrow biopsy in patients with human immunodeficiency virus infection. Rev Clin Esp. 1996;196:9-15.

Patwardhan B, Mashelkar RA. Traditional medicine inspired approaches to drug discovery: can Ayurveda show the way forward? Drug Discov Today. 2009;14:804-811.

Patwardhan B, Vaidya ADB. Natural products and drug discovery. Indian J Exp Biol. 2010;48:220-227.

Paul H, Taylor JW, Burce GD. The Effects of Social Class and Perceived Risk on Consumer Information Search. J Cons Market. 1987;4:41-46.

Pillai NK. History of Siddha Medicine. (Chennai, India: Government of Tamil Nadu), 1979.

Prasad LV. In: Indian System of Medicine and Homoeopathy Traditional Medicine in Asia. Chaudhury Ranjit Roy, Rafei Uton Muchatar., editors. (New Delhi, India: WHO- Regional Office for South East Asia), pp. 283-286, 2002.

Raina MK. Quality control of herbal and herbo-mineral formulations. Indian J Nat Prod. 2003;19:11-15. 
Rajagopalan TG. Traditional Herbal Medicines around the Globe: Modern Perspectives. The Indian Perspective Proceedings of the $10^{\text {th }}$ General Assembly of WFPMM, Seoul, Korea. Swiss Pharma. 1991;13:63-67.

Rajalakshmi A, Baby Malathi S, Kanimozhi S, Nilakkalli N. A Literary Review of Kayakalpa Plants in Siddha Literature. 2006. Available at:http://openmed.nic.in/1470/ (accessed on $24^{\text {th }}$ January 2012).

Ram A, Joseph DA, Balachandar S, Singh VP. Medicinal plants from Siddha system of medicine useful for treating respiratory diseases. Int J Pharm Anal. 2009;1:20-30.

Ranga RS, Sowmyalakshmi S, Burikhanov R, Akbarsha MA, Chendil D. A herbal medicine for the treatment of lung cancer. Mol Cellul Biochem. 2005;280:125-133.

Rao KK, Veluchamy G. Siddha medicine and its usefulness in Day-Today Life. Subramanian, S.V., Madhaven, V.R. (Eds), Heritage of Tamil Siddha medicine. (Madras, India: International Institute of Tamil Studies), pp. 171-184. 1983.

Rao M, Rao KD, Shivakumar AK, Chatterjee M, Sundararaman T. Human resources for health in India. Lancet. 2011;377:587-598.

Ravishankar B, Shukla VJ. Indian Systems of Medicine: A Brief Profile. Afr J Tradit Complement Altern Med. 2007;4:319- 337.

Richard NC. An Experimental Study of Consumers Effort, Expectation, and Satisfaction. J Market Res. 1965;244-249.

Roberson E. Medicinal Plants at Risk. Nature's Pharmacy, Our Treasure Chest: Why We Must Conserve Our Natural Heritage. 2008. Available at: http://www.biologicaldiversity.org/ publications/papers/Medicinal_Plants_042008_lores.pdf (acces sed on $12^{\text {th }}$ January 2010).

Robert P, Brody J, Cunningham SM. Personality variables and the Consumer Decision Process. J Market Res. 1968;5:53-57.

Sambasivapillai TV. Dictionary based on Indian medical science. (Chennai, India: National Institute of Siddha), 1931.

Sampath CK. Evolution and development of Siddha medicine. Subramania S.V. and Madhaven V.R. (Eds), Heritage of Tamil Siddha medicine. (Madras, India: International Institute of Tamil Studies), pp.1-20, 1983.

Saroja PR, Veluchamy G. Simple medicine in Siddha system. Subramanian S.V. and Madhaven V.R. (Eds), Heritage of Tamil Siddha medicine. (Madras, India: International Institute of Tamil Studies), p.185, 1983.

Sarwade WK, Ambedkar B. Emerging Dimensions of Buyers Behavior in Rural Areas. Indian J Market. 2002;32:13-21.

Shanmuga Velan A. Siddhar's science of longevity and Kalpa medicines of India. Madras: Sakti Nilayam, 1963;4:67-68.

Sharma DC. India to regulate indigenous medicine sector. Lancet. 2001;358.

Sneader W. Drug Discovery: a History. (Chichester, UK: Wiley), 2005.
Solecki R. Shanidar IV, a Neanderthal flower burial in northern Iraq. Science. 1975;190:880-881.

Somasundaram S. MaruthuvaThavaraviyal (Medicinal Botany). (Palayamkottai, India: Elangovan Publishers), p 3, 1997.

Sowmyalakshmi S, Nur-E-Alam M, Akbarsha MA. Investigation on Semecarpus Lehyam - a Siddha medicine for breast cancer. Planta. 2005;220:910-918.

Subbarayappa BV. Siddha medicine: an overview. Lancet. 1997;350:1841-1844.

Thas JJ. Siddha medicine--background and principles and the application for skin diseases. Clinics Dermatol. 2008;26:62-78.

Uthamaroyan CS. Siddha Maruthuvanga Churukkam (Treasure of Siddha medicine). Tamil Nadu Government Siddha Scintific Committee Publication, India, 1983. pp 10. (In Tamil).

Veena K, Shanthi P, Sachdanandam P. Therapeutic efficacy of Kalpaamruthaa on reactive oxygen/nitrogen species levels and antioxidative system in mammary carcinoma bearing rats. Mol Cell Biochem. 2007;294:127-135.

Veluchamy G, Ravi Shankar V. Siddha System of Medicine A profile and focus on research and development. (New Dehli, India: Central Council for Research in Ayurveda and Siddha), pp. 31-43, 1986.

Veluchamy G, Thayagarajan R. Practical difficulties in assessing the merits of Siddha drugs. (New Dehli, India: S.V. Subramanian and V.R. Madhavan ), 1983.

Walter TM, Rubia G, Sathiya E. A review of Ethics in Traditional Siddha Medicine as defined by Siddhar Theraiyar. Siddha Papers. 2009;2:1-6.

Walter TM. Malaria as "Kulir Suram" in traditional Siddha medicine. 2005. Available at: http://openmed.nic.in/1199/01/ Malaria_as_kulir_suram.pdf (accessed on $24^{\text {th }}$ January 2012).

WHO. General guidelines for methodologies on research and evaluation of traditional medicine. World Health Organization, Geneva, Switzerland. 2000. WHO/EDM/TRM/2000.1. Available at: http://whqlibdoc.who.int/hq/2000/WHO_EDM_ TRM_2000.1.pdf (accessed on 05th May 2012).

Zhang X. Regulatory situation of herbal medicines - a worldwide review. World Health Organization, Geneva, Switzerland. 1998. Available at: http://apps.who.int/ medicinedocs/pdf/whozip57e/whozip57e.pdf (accessed on $25^{\text {th }}$ May 2012).

WHO. Traditional Medicine Strategy 2002-2005. World Health Organization, Geneva, Switzerland. 2002. WHO/EDM/TRM/2002.1. Available at: http://whqlibdoc.who. int/hq/2002/who_edm_trm_2002.1.pdf. (accessed on 25 ${ }^{\text {th }}$ May 2012).

Wilson E, Rajamanickam GV, Vyas N, Agarwal A, Dubey GP. Herbs used in Siddha Medicine for Arthritis - A Reviw. Indian J Trad Know. 2007;6:678-686.

Wujastyk D. Medicine in India. Alphen JV, Alphen J, Aris A, De Fraeye M, Meyer F. Oriental Medicine: An illustrated 
Tamil traditional medicinal system - Siddha Karunamoorthi

Guide to the Asian arts of Healing. (London, UK: Serindia Publications, Inc.), p. 31, 1995.
Zysk KG. Siddha Medicine in Tamil Nadu. (Denmark: The Tranquebar - Initiative of the National Museum of Denmark, Frederiksholms Channel 12), 2008. 